10. Професійна освіта: словник: навч. пос. / ред. Ничкало Н. Г. Київ: Вища школа, 2000. 380 с.

11. Milkova R. Competency and Skills of the Person - Strategy of University Education during 21st Century // Strategies for Policy in Science and Education. 2015. Vol. 23, Issue 1. P. 38-64.

Рекомендовано до публікації д-р пед. наук Рябова 3. В. Дата надходження рукопису 23.10.2018

\begin{abstract}
Малінкіна Валентина Леонідівна, кафедра педагогіки, управління та адміністрування, Державний вищий навчальний заклад "Університет менеджменту освіти" Національної академії педагогічних наук України, вул. Січових стрільців, 52-а, м. Київ, Україна, 04053

E-mail: malinkina.valentina@i.ua
\end{abstract}

УДК 378.147

DOI: $10.15587 / 2519-4984.2018 .152388$

\title{
METHODS AND FORMS OF TUTORING AND MENTORING AT HIGHER EDUCATIONAL ESTABLISHMENTS OF GERMANY
}

\author{
(C) O. Ivanytska
}

У статті виконано аналіз методів і форм тьюторства та менторства у закладах вищої освіти Німеччини. Дослідження включає порівняльний аналіз різних ЗВО Німеччини, спільні риси та відмінності при реалізації тьюторства та менторства. Зазначено, щзо Німеччина входить до ряду крайн, в яких система тьюторства та менторства реалізується на найвищому рівні з урахуванням особливостей різних $3 В О$. Варто зазначити, щчо особливу роль в координачії роботи тьюторів та менторів у закладах вищої освіти Німеччини відіграє Мережа тьюторів. Мережа забезпечує спілкування між спеціалістами різних ЗВО, відповідає за вирішення складних ситуацій та розробляє стратегію на наступні роки. Окремої уваги заслуговує кваліфікація тьюторів. Незважаючи на відмінності системи тьюторства та менторства у різних 3ВО, існують загальні принципи функціонування відповідно до автономності кожного закладу вищої освіти. Більшу увагу приділяють підготовці тьюторів, оскільки ментори, здебільшого, $\epsilon$ прачівниками ЗВО, виконують організаційні та психологічні функиї і є спеціалістами відповідно до свого освітньо-кваліфікаційного рівня. Тьютори проходять ряд кваліфікаџійних заходів, семінарів та тренінгів. В кінцевому результаті вони отримують сертифікати. Під час тренінгів та навчальних модулів для тьюторів, їх не лише навчають методики викладання, але й ознайомлюють з кейс-методами для вирішення конкретних проблем. Це зумовлено збільшенням кількості іноземних студентів та необхідності в нестандартних підходах в роботі з іноземиями. Стаття також відображає змімення акцентів в тьюторській та менторській діяльності. Якщо, кінещь ХХ століття характеризується появою тьюторства та менторства у більшості ЗВО, початок XXI століття - системністю тьюторської та менторської діяльності, то на сьогодні особливий акцент робиться на кваліфікації та сертифікації тьюторів. В статті показано, що рівень готовності тьюторів до проведення тьюторіалів безпосередньо впливає на успішність студентів та забезпечення якості в навчальному процесі

Ключові слова: тьютор, ментор, тьюторіал, кваліфікація тьюторів, забезпечення якості у в вищій ocвimi

\section{Introduction}

The research of tutoring and mentoring at higher education belongs to the topical issues in the system of higher education. Tutoring and mentoring is successfully implemented at the leading world universities. Germany belongs to the countries with the most developed system of tutoring and mentoring. The correct implementation of tutoring and mentoring at HEEs influences directly on the success of the specific HEE and its students. Nowadays, German HEEs pay much attention to methods of tutoring and mentoring in order to provide quality assurance in the educational process and make the work of tutors and mentors more professional. The forms of tutoring and mentoring differ depending on each HEE. Wellstructured preparation of tutors helps them in their future. Especially, it is important to those who will continue their teaching activity. The role of the Network of tutors is highly considerable in providing guidelines, coordination and support. The exchange of ideas among specialists of HEEs during the Network meetings influence on the methodology and forms of tutoring and mentoring activity as well as enrichment of tutorials by qualitative teaching performance.

\section{Analysis of references and problem state-} ment

The issues of tutoring and mentoring have been researched by numerous scholars in the world. The biggest amount of research is done by American and English scientists. It is caused by the fact that first forms of tutoring and mentoring in higher education appeared in England. Besides, foreign researchers pay attention to the issues of the teaching process organization as well as professional development of teachers [1]. It goes without 
saying, that German scientists have been researching the system of tutoring and mentoring in the broadest meaning, knowing its peculiarities. The research that influences tutoring and mentoring development in Germany in the nearest future belongs to the XXI century. Significant contribution to this problem was made by researchers who, besides their scientific activity, work at HEEs and participate in the tutoring and mentoring realization process or belong to the Network members. Significant contribution was made by such representatives who combine scientific and practical work and have several compound publications about tutoring and mentoring. These works outline practical issues application and details on tutors' qualification [2, 3]. Besides, German scholars pay attention to the issues of quality assurance in higher education [reference] [4]. Methods and forms are discussed during the Network meetings. All these discussions and new ideas form the basis of new research papers. Therefore, our references list includes several sites of HEEs and the Network as the information analyzed in our paper is new and outlines the discussions during the Network meetings. Also there is a serious number of the adjacent topic research. This includes study of distance learning, internationalization strategies, academic mobility, quality assurance in higher education etc. While researching tutoring and mentoring methods and forms, scholars take into consideration the participants of tutorials, their cultures and objectives of study at German HEE.

Concerning Ukrainian research, the number of publications, devoted to distance learning and peculiarities of higher education reforming, has increased [5]. We believe that research of tutoring and mentoring methods and forms will broaden our understanding of tutoring and mentoring system of Germany. In our opinion, methods, which are used in tutorials, could be applied at the Ukrainian HEEs at distance learning now and for the tutoring and mentoring research in general with possibilities of future application.

\section{Aim and objectives of the research}

The purpose of the research is to analyze methods and forms of tutoring and mentoring at German HEEs in order to use the best practices in Ukraine in frames of higher education reforming.

The following tasks have been set for the purpose achievement:

1. To analyze forms and methods of tutoring and mentoring at German HEEs;

2. To outline the peculiarities of the methodology used in tutorials at German;

3. To define the key indicators that influence quality assurance of the teaching process at German HEEs.

\footnotetext{
4. Practical application of tutoring and mentoring at Higher Educational Establishments of Germany

In the research of tutoring and mentoring at German HEEs great attention should be paid to the Network of tutors which is responsible for the coordination of the tutoring and mentoring process. The Network is responsible for meetings with the Network memebrs; provision of an online platform for the exchange of experience and results of educational activities; organization of activity on the relevant topic;
}

establishing a dialogue with the leadership of higher education institutions. Among the priorities of the Network today is the provision of greater prestige and recognition of the qualifications of tutors. The Network has been accrediting qualification programs for tutors. The request for accreditation may be submitted by the responsible person or coordinator of the tutoring and mentoring program from each HEE. A certificate of accreditation is presented at the meetings of the Network [6].

Depending on their qualifications, tutors can perform various functions and are accordingly selected to perform these functions at their HEE. For example, subject tutors have professional qualifications.

An important role in the organization of tutors belongs to the coordinators who work at HEEs, at some HEEs mentors are also responsible to some extend for tutors preparation.

A significant advantage of tutoring for each tutor in particular is the ability to continue academic activities. Teaching activities can be the first step towards the future career of a teacher and a scientist, since it provides an opportunity to gain practical experience in working with students and in the teaching process.

As we have mentioned, the forms of tutoring and mentoring organization differ at every HEE. For example, Welcome and Stay program is responsible for comfortable training of all students at the Mittelhessen University of Applied Sciences. As a part of this program, the international department closely cooperates with the department of tutoring and mentoring. The program provides advice on the educational process, the adaptation of foreign students to life in Germany, and to obtain a diploma as a result. Students usually need help in finding housing, financial support, permitting documents, organization of training and practice, studying abroad, etc. The International Get-Together program aims to develop the academic German language, learn foreign languages, and promote socio-cultural adaptation in line with the trends and customs of German society. Also, there is the International Buddy Program (IBP) in frames of which tutors and mentors act as friends for the faster adaptation of foreigners. The aim of the program is to provide intercultural exchange and support international students at an early stage. Students have the opportunity to meet regularly with their mentors. For tutors, work in this area provides an opportunity to gain valuable experience as they constantly seek the necessary information for junior students and, accordingly, deepen their own knowledge of studying abroad, the development of intercultural competences, and also have the opportunity to find new friends. Also, excursions, events on intercultural awareness and workshops are organized within this program. Most events are free for participants. During such events there is an opportunity to meet and chat with your friends. Meetings take place in a relaxed atmosphere in the game format. Students are also encouraged to bring dishes that are traditional in their countries. Students get acquainted, establish contacts, communicate in foreign languages, share experiences in participating in international programs. During the semester workshops are organized related to such issues as employment, filling in application forms for employment, organization of student life in a foreign country, etc. The semesters end with 
a party, during which summed up, determine the advantages and disadvantages [7].

Concerning the payment issues, on average, the tutor earns 10 euros per hour of his work and works for 22-25 hours, some masters work for more. At some universities tutors may earn even 450 euros a month [7, 8].

The very system of tutoring at German HEEs is organized approximately in the following way: firstly, there are standard lectures which are delivered by professors for about 350 students, after which tutorials are organized, during which tutors help to understand practical issues. Some tutorials are obligatory, others are not.

The University of Fulda uses the potential of etutoring and virtual qualification courses. Tutors after courses receive certificates with their qualifications [9].

The university nowadays pays a lot of attention to the evaluation of tutors work. There should be a team of experts who need to evaluate the process, but, unfortunately, there are no such experts at each university.

While talking about methodology, we should mention the Center for Cooperative Teaching and Learning ZekoLL which operates at the Mittelhessen University of Applied Sciences. The task of the center is to organize the teaching and development of tutors; development and organization of training programs; organization of trainings and tutors training; coaching, which includes didactic support for teachers; mentoring; E-learning; individual projects. The center also offers a variety of counseling and advanced training opportunities, its team helps students to apply new teaching and learning methods. In addition, they support collaboration within and outside the University and moderate the exchange of knowledge between the participants in the educational process. If teachers want to introduce new methods, they will be advised during the entire semester. It should be noted that about 50 students have about 3 tutors, that is, 1 tutor - for 15 students. There is sometimes 1 tutor for 50-60 students. There are situations when 1 tutor works with 2-3 students. In this case, they work very intensively. Professors recommend the best students for tutor activity and sign a contract with them. The center of tutoring prepares tutors, improves their qualifications. They get a certificate and permission to be tutors [7].

A necessary element in the organization of tutoring and mentoring is the evaluation in the work of the tutorials. Fulda High School seeks to improve the quality of teaching through regular assessment. Students must be involved in the assessment of teaching. The supplements of the methods and tools used are carried out through a dialogic evaluation: this can be a conversation format; systematization and analysis of evaluation of the teaching and learning services department [9].

A German scholar Heike Kröpke pays much attention to a methodology in the tutoring process. She believes that tutors are given specific assistance and information on specifics of teaching activities that provide or optimize the success of tutoring. To manage the group it is necessary to have both the necessary know-how and methodical-didactic tools [2].

In qualifying seminars for tutors, they usually discuss their concerns and problems with their tutorial work.
We should note that tutors are very much interested in certification. Certification offers tutors the obtaining of the complex qualification, necessary for educational activities, as well as proposals for the development of social, methodological and personal competences (soft skills) with which they can reveal their individuality. Professors also encourage highly active tutors, confirming their activity by a letter of recommendation which may help them for future employment. Through their participation in trainings, they acquire additional, valuable competencies, such as social, methodological and personal.

Tutors must learn about new educationalpsychological and didactic approaches; be able to combine new information, obtained with prior knowledge or experience; to master the educational material; analyze their own teaching and learning behavior; perfectly master the methods of seminars; exchange interdisciplinary experience [3].

We would like to show the practical application of tutoring on the example of two universities - the Mittelhessen University of Applied Sciences and Fulda University of Applied Sciences.

Students of some specialties at the Mittelhessen University of Applied Sciences have the opportunity to receive ECTS credits for attending modules related to their own teaching activities, conduct open tutoring classes and provide self-review report. After the completion of theoretical and practical training, the results are presented in the report, which indicates the content of qualifications, their own teaching practice and understanding of tutor role. The module is evaluated on the basis of transparent criteria. The tutors go through several qualifications. Basic qualification (4 hours) includes the following components: tutoring management; methodical, personal; social and professional competence; work on mistakes, activating students on mathematical tutorials by means of surveys and work on the training board. Further qualification for teaching (6 hours): academic writing, methodological and personal competence, development of educational videos for working with tablets and the beginning of their use, application of presentation techniques in the student and teaching environment. Further qualification for teaching (6 hours) consists of communication and management of groups - methodical, social and personal competence; tutoring research methodological and social competence; tutoring of projects -methodological, personal and social competence; intercultural educational work -personal and social competence. Further qualification (4 hours) includes language tutorials - professional and methodological competence; counseling, support, tutors counseling - social and personal competence etc. Further qualification (4 hours) consists of moderation - methodical and personal competence; conflict management - social and personal competence; workshops design - methodical and personal competence; methodical seminar / experiment, training on methodical competence [7].

It is also important to indicate that tutors should complete basic training (4 hours); + / or additional qualification (6 hours) / additional qualification (4 hours) and meeting for feedback ( 2 hours); / or 2 open lessons with feedback conversations and meetings; together -10 -hours 
qualification. Accordingly, the tutors have the following capabilities: basic qualification (4 hours) / additional qualification (6 hours) / additional qualification (4 hours) and 2 hours - meeting for reviews / open lessons (4 hours) and meeting for feedback c2 hours. There is also an online survey for tutors to receive feedback [7].

The University of Applied Sciences in Fulda proposes a program with the further obtaining of the Certificate which consists of both compulsory and optional components. The compulsory course must be completed before participating in other optional courses. The certificate "Work at the universities" includes: mastering of the basic course - 15 academic hours; 2 optional modules (10 academic hours); additional module "Planning of tutorials" (5 academic hours); report-analysis (10 academic hours); additional module "Collegiate situational counseling" (5 academic hours). Tutors can choose the sequence of participation in the events themselves. The certificate "Work at the tutorials" provides: the basic course -15 academic hours; report-analysis -6 academic hours; combined study "electronic tutorials" - 24 academic hours [9].

Through participation in trainings and practical classes, tutors can obtain or optimize the following competencies: professional competence; methodological competence (educational material, prepared methodically and didactically, in order to achieve participants success and motivation in education); social competence (tutors are ready to help, they are open to questions and problems); personal competence (personal skills, such as motivation, autonomy, activity and time management); competence of group management; competence of communication in a group (complex situations are discussed with a group or with an individual); rhetorical competence (the formulation and presentation of the material is oriented to the listener).

An important tool is the choice of presentation methods for material content. First of all, the choice of methods is carried out with the purpose of a constructive educational environment formation and successful mastering of the material. The choice of methods is determined by the content of the educational material, the educational objectives, taking into account the specifics of the audience, the general conditions and the knowledge, skills and abilities of the tutor. Combination of various learning methods should be implemented in each particular learning situation.

There are methods of presentation: a brief report, a lecture, a film, etc. When using these methods, participants become listeners. With the help of entry methods, participants get to know each other, set up first contacts and thus lose insecurity. Communicative spoken methods include classroom conversations, group discussions etc. Activating teaching methods consist of role-playing games, examples of real situations, business games, work in small groups etc. When using these methods the participants become active creators of the learning process.

Unfortunately, there is no recipe for applying this or that method. The methods should be selected in each particular situation for particular audience and specific purpose [4].

Also we should mention about cooperative learning methods. They support a transparent learning process; provide diversity in the learning process; give an opportunity to actively involve all students; extend soft skills for study and occupation; facilitate the transition from teaching to learning. Research methods can be quantitative and qualitative. Quantitative study includes the interaction between the duration of training and the result of the test; general statements about teaching. Qualitative consists of research of individual cases.

It goes without saying, that use of the foreign experience is especially valuable in the system of distant learning in Ukraine [5]. Especially it is related to tutoring, which directly influences on students success and quality assurance in higher education [10].

In our opinion, the German experience is extremely important for us especially now in the period of significant technological changes. Nowadays, the proper use of technology can enhance quality learning. Using new technologies in teaching may be also an option to familiarize students with innovations that may be needed in their future. Some universities already provide online learning and provide professional development of their teachers. However, many teachers still lack the skills for using new innovations in teaching [1]. In this situation German HEEs are very advanced. Besides well prepared teachers, there are tutors who have been taught the best practices during tutorials as well as special departments which are responsible for the realization of tutoring and mentoring and a variety of teaching methods providing.

\section{Research results and their discussion}

After the analysis of references and conducted analytical work on tutoring and mentoring forms and methods at German HEEs we have defined the common and different features for all universities.

This research shows the development of tutoring and mentoring methods in Germany and increase of attention to the qualification of tutors. We believe that qualification of tutors and systematic approach in tutoring and mentoring activity provides quality assurance at Higher Educational Establishments of Germany as well as creates comfort conditions for all students.

\section{Conclusions}

The research of tutoring and mentoring forms and functions at German HEEs allows to make the following conclusions:

1. Tutoring and mentoring is professionally organized at the most German Higher Educational Establishments.

2. Tutoring and mentoring is controlled on the University level, besides there is the Network of tutors which coordinates the tutoring and mentoring activity in the whole Germany.

3. Nowadays, the specific accent is made on qualification of tutors and finally the providing them with the certificates.

4. It is researched, that variety of methods used at tutorials directly influence students success and provide quality assurance in educational process.

We believe that we should learn the experience of German HEEs in the field of tutoring and mentoring real- 
ization in order to use the best practices at higher education of Ukraine. Nowadays, we have the possibility to use foreign practices in frames of the university autonomy and higher education reforming in Ukraine.

\section{References}

1. The professionalization of Academics as Teachers in Higher Education. Standing Commettee for the Social Sciences (SCSS) / Pleschova G. et. al. // Science Position Paper. 2012. P. 32.

2. Kröpke H., Brinker, T. Das Tutorenprogramm an der Hochschule Niederrhein / ed. by Eckehard M. Wer, wo, wie und wie viele Schlüssel-Kompetenzen? Wege und Erfahrungen aus der Praxis an Hochschulen. Recklinghausen, 2008.

3. Kröpke H., Szczyrba B. Wer stützt den Sherpa? Tutorenweiterbildung als Investition in Qualität der Lehre / ed. by Behrendt B., Voss H.-P., Wildt J. // Neues Handbuch Hochschullehre (Griffmarke F 6.5). Stuttgart: Raabe, 2006.

4. Wörner A. Lehren an der Hochschule. Eine praxisbezogene Anleitung. Wiesbaden: Verlag für Sozialwissenschaften, 2006.

5. Maliarchuk O. V. Vykladach v systemi dystanciynoho navchannia // Pedagogical process: theory and practice. 2009. Vol. 2. P. $169-178$.

6. Netzwerk Tutorienarbeit an Hochschulen. Available at: http://www.tutorienarbeit.de/

7. The Mittelhessen Univeristy of Applied Sciences. Available at: https://www.thm.de/site/

8. University of Wuerzburg. Available at: https://www.uni-wuerzburg.de/en/university/

9. Fulda University of Applied Sciences. Available at: https://www.hs-fulda.de/en/

10. Ruiz N., Fandos M. The role of tutoring in higher education: improving the student's academic success and professional goals // Revista Internacional de Organizaciones. 2014. Issue 12. P. 89-100. doi: http://doi.org/10.17345/rio12.89-100

Рекомендовано до публікаџії д-р пед. наук Мукан Н. В. Дата надходження рукопису 23.10.2018

Oksana Ivanytska, Assistant, Department of Pedagogics and Social Management, Lviv Polytechnic National University, S. Bandery str., 12, Lviv, Ukraine, 79013

E-mail: kseniaivanytska@ukr.net

\section{УДК 54:378.14}

DOI: $10.15587 / 2519-4984.2018 .153375$

\section{ВИКОРИСТАННЯ ТЕХНОЛОГІЙ ЕДЬЮТЕЙНМЕНТ В МЕТОДИЦІ НАВЧАННЯ ХІМІї В ШКОЛІ}

\section{(C) М. В. Пасічник}

Стаття направлена на дослідження можливості використання освітніх технологій едьютейнмент $в$ икільному курсі хімії. Термін едьютейнмент (edutainment) був отриманий за допомогою злиття двох англійських слів — "еdисатіоп" (навчання) та "entertainment” (розвага). Однією з переваг використання технологій-едьютейнмент при вивченні шкільного курсу хімії є, те, щуо учні можуть засвоювати нові когнітивні навички. Наприклад, розвивають логічне мислення та просторове відчуття, вчяться співпрацңювати, щуо готує їх до подальшого навчання та розв'язання інших проблемних ситуацій. В статті представлений аналіз деяких мобільних додатків та комп'ютерних програм які можна використовувати в шкільному курсі хімії. Очінені основні характеристики програм. Встановлені переваги проблеми й перспективи їх використання та здійснений аналіз шкільної програми з курсу хімї 7 клас на прикладі підручника «Хімія 7 клас» автор Г.А. Лашевська. В статті представлені основні теми з 7 класу по підручнику, які можуть бути доповнені технологією едьютейнмент.

При вивченні хімії в 7 класі доцільним буде використання відео-уроків Thoisoi ma Smart Learning for All. B 7 класі учні вперше стикаються з хімією як наукою, використання відео добірок дозволить сформувати в учнів уявлення про будову молекули та розвинути в них абстрактне мислення.

Так в статті описано, щуо використання гри МарсХімПром при вивченні хімії може стати для учнів випробуванням з вирішення комплексних актуальних проблем або проектів, які вони можуть сприйняти, чи відхилити. Мобільний додаток MEL Chemistry: 3D надасть учням інструменти та ресурси, щуо необхідні для розуміння проблеми і для ї̈ вирішення, а також дозволяють учням досліджувати, експериментувати, конструювати, спілкуватися й міркувати над тим, щзо вони роблять - тобто навчатися на особистому досвіді.

В контексті даної теорії, навчання з використанням освітньої технології едьютейнмент відбувається через розв'язання проблем за допомогою обраного учнем способу ї̈ розв'язання. Здобутий при изьому досвід збагачується рефлексією, становлячись глибшим

Ключові слова: технологї едьютейнмент методика навчання хімії, икільний курс хімї, мобільне навчання 